\title{
伝統的な居住様式に対する災害の被害・外部支援の影響
}

2018 年ロンボク島地震の被災地バヤンを事例として

\section{THE IMPACT OF DISASTER DAMAGES AND TEMPORARY SHELTER CONSTRUCTION ON THE TRADITIONAL WAY OF LIVING}

Case of Bayan, Indonesia after the Lombok earthquake in 2018

\author{
有年 秀介*1, グレゴリウス・アグング・セトヨヌグロホ*2, 牧 紀 男 ${ }^{* 3}$, 脇 田祥 尚*4, \\ 竹内 泰*5, 張 漢 賢*6, 笹谷 満*7

\section{Shusuke ARITOSHI, Gregorius Agung SETYONUGROHO, Norio MAKI, Yoshihisa WAKITA, Yasushi TAKEUCHI, Hon Shyan CHONG and Mitsuru SASATANI}

\begin{abstract}
The goal of this paper is to clarify the influence of damage, and temporary housing to the traditional living styles in Bayan after the 2018 Lombok earthquake. Following results were acquired from the analysis of field survey data. 1) There were disturbances about the pre-disaster way of life because of all the activities were done in outside. 2) Temporary shelter construction helped to recover the life style of pre-disaster by supplying safer sleeping space. 3) The relation among main building, terrace and Berugak were kept even though a temporary shelter were injected into the housing complex.
\end{abstract}

Keywords: Lombok earthquake, Life recovery, Temporary shelter, traditional lifestyle, Housing recovery ロンボク島地震，生活再建，仮設住居，伝統的な住まい方，住宅再建

\section{1. はじめに}

アジア地域の災害では、被災した地域に対して国際機関やNGOな どによる支援が行われるが、被災地の生活再建支援において再建の 主体である地域住民の意向があまり尊重されていないこと1などが 問題点として挙げられている。地域住民への配慮を欠いた生活再建 支援は地域の伝統的な生活文化に影響が出る恐れがある。なかでも 仮設住居は一時的なものではなく再建住居が建設後も利用されてい るという報告2)もあり、仮設住居は地域の生活文化を乱す可能性が ある。仮設住居が被災者の生活再建や住民の生活文化に与える影響 を明らかにすることで、今後の災害復興における支援のあり方を考 えるうえで意義があると考える。

本研究は、2018年7月ならびに8月にインドネシア・ロンボク島で 発生した地震で多大な被害を受けたロンボク島北部のバヤンを対象 として、地震の被害、外部からの支援者により提供された仮設住居 がこの地域の伝統的な住まい方を変化させてしまうのではないか、 という仮説にもとづき、集落の住民の被災後の住まい方から、地震 の被害、仮設住居が被災者の生活再建と伝統的な住まい方の構成に 与える影響を明らかにすることを目的とする。
調查地であるバヤンは地震発生前から調查が継続的に行われてお り注1)、伝統的な居住様式を有していることが明らかになってい る。これらの居住様式の災害時における役割について考察を行う。 災害復興に関する研究は数多くあり、本研究の対象地である東南 アジア地域の復興についても多岐にわたる研究がある。前田ら ${ }^{1)}$ は、スリランカ南西海岸の被災地を対象に、外部支援によらず相互 扶助的な近隣関係により自力復興がなされた地域と外部の支援者に より復興が進んだ地域での対照的な復興の実態を明らかにしてい る。林ら ${ }^{3)}$ は2006年ジャワ島中部地震の被災地を対象に、生活再建 の実態の調査を行った。世帯によって支援の金額が違うなどの現金 給付による生活再建支援策の問題点を指摘している。

また、災害復興における伝統的建物や空間に焦点を当てた研究と しては山崎ら ${ }^{2)}$ が、ジャワ島中部地震の被災地の集落を対象に再建 過程における伝統的な住居の配置や敷地構成一の影響を明らかにし ているが、被苂後の住まい方の分析事例は少ない。

ロンボク島の住居や集落を対象とした研究としては、脇田らのグ ループによる研究があり、25年前 ${ }^{4}$ から継続的にバヤンの住居や集 落の空間構成についての調查研究を行っており、バヤンの住居平面
*1 元京都大学大学院工学研究科大学院生 修士 (工学)

*2 アトマジャヤ大学工学部建築学科 講師・修士 (工学)

*3 京都大学防災研究所 教授. 博士 (工学)

*4 近畿大学建築学部建築学科 教授 ·博士 (工学)

*5 東北工業大学建築学部建築学科 教授 · 博士 (工学)

*6 公立鳥取環境大学環境学部環境学科 教授・博士 (工学)

*7 積水ハウス 修士 (工学)
Former Grad. Stud., Graduate School of Engineering, Kyoto Univ., M.Eng.

Lect., Faculty of Engineering, Atma Jaya Univ. Yogyakarta, M.Eng.

Prof., Disaster Prevention Research Institute, Kyoto Univ., Dr.Eng.

Prof., Faculty of Architecture, Kindai Univ., Dr.Eng.

Prof., Faculty of Architecture, Tohoku Institute of Technology, Dr.Eng.

Prof., Faculty of Environmental Studies, Tottori Univ. of Environmental Studies, Dr.Eng.

Sekisui House, Ltd., M.Eng. 
構成の変遷(5)6 についての研究を行っている。同チームによりロン ボク島地震に関する研究も行われており、被災地のバヤンの住居の 被害状況や生活再建初動期における生活空間の実態》を明らかにし ている。本研究では、同チームによる研究の一環として行うもので あり、仮住まい期（災害から 1 年後）を対象とするものであり、ロ ンボク島地震から1年が経過した2019年8月 (2019年8月11日から 16 日)に実施した、仮設住居の実測や生活空間のインタビュー調查に もとづくものである注2)。

\section{2. ロンボク島地震と調査地の概要}

\section{2-1 ロンボク島地震と復旧・復興}

2018年7月29日にインドネシア・ロンボク島北部を震源とするマ グニチュード (M) 6.4の地震、8月5日にM7.0の地震が発生した。その 2週間後の8月19日にM6.5ならびにM6.9に地震が発生した。被害につ いては、インドネシア国家防災庁 (BNPB) ${ }^{8)}$ が2019年1月20日に発表し たデータによると、ロンボク島全体で死者564名(うちロンボク島北 部では469名)であった。避難者は47万人(うちロンボク島北部で 178,122 人)、損壊建物は 216,489 棟 (うちロンボク島北部で 49,853 棟)であった。Fig.1にバヤンBayanの位置、震源地を示す。

調査地であるバヤン村の東バヤン地区で地震発生1か月後の 2018 年9月に調查 ${ }^{7)}$ 行った。被害の多くは近代化した無補強組積造の建 物であった。伝統的住居は構造的には大きな被害を受けることはな かった。付属建物で被害を受けているものもあるが、6本柱の屋根 付き露台であるブルガはほとんど被害が無く地震後も使用されてい る。

ロンボク地震後、2018年7月29日に非常事態宣言が出され、2018 年8月 25 日まで何度か延長された。2018年8月26日から 2019 年 2 月 26 日までが非常事態から復興への移行期間となった。2月27日から復 旧・復興段階となった。政府は住居の被害レベルに応じた金額の支 援を行った。9)注3)

政府は再建住居の支援を主導していたが、調査時点では仮設住 居などの支援は行っていなかった。仮設住居の支援はNPOやNGOなど が主体となっていた。本研究の調査地であるバヤンはNPOのYayasan Bumi Tangguhによって仮設住居の提供が行われた。

\section{2-2 集落の概要}

調查地であるバヤンは、ササック族がすむロンボク島北部に位置 する集落である。聖山であるリンジャニ山(標高 $3726 \mathrm{~m}$ )の北側斜面 に位置する。山からの豊かな水に恵まれ、集落周辺は棚田で囲まれ る農村集落である。中心部の小高い丘には、1992年に文化財として

指定された木造のモスク (1634年に建てられたという説もある)が建 てられ、その周囲には当時この地にイスラーム教を伝えたとされる 聖者の墓が配置されている。集落内にはいくつかの祭祀場カンプ Kampuがあり、祭祀の際にのみ用いられるルーマー・アダットrumah adat (慣習家屋) と呼ばれる伝統的住居が見られる。本論文で対象と する東バヤン地区は、モスクの南側に位置する。西には地域の幹線 道路を挟み西バヤン地区があり、南側には隣接して集落内の他の住 区がある。東には道沿いに山からの水を運ぶ小川が流れており、そ の東には棚田エリアが広がっている。東バヤン地区北側中央にはカ ンプが位置し、カンプ内には3棟の伝統的住居、祭祀の際に使われ る7棟のブルガ、1棟のかまや・穀倉がある。

2-3 被災前の住まい方 (Fig. 2)

バヤン村には、6本柱の屋根付きの高床式の露台であるブルガ (Photo 1) や、イナンバレ (Photo 2) と呼ばれる6本柱の倉庫を持つ 住居が見られる。ブルガは日常生活の場として重要な役割を果たし ており、睡眠、炊事・食事の準備、作業、休息、懇談など多目的に 使われている。ブルガは主屋注4) の前面に平行に配列されるのが基 本的な形態で、主屋、テラス、ブルガで一体となった空間を作り出 している。伝統的住居に設けられるイナンバレは、日常的には高床 の倉庫としての役割を果たし、米や野菜、监などが収納されている が、儀礼時には、カンプの住居のイナンバレは、女性の祭祀者が 籠って祈りをささげるなどの儀礼行為を行う場所になる。イナンバ レは住居内の神聖な空間として伝統的な形式を今に伝えるものだと 考えられる。

1992年から1994年にかけて東バヤン地区で行われた現地調查 ${ }^{4}$ に よると、イナンバレを有する住居は、祭祀エリアを除くと、37棟中 6棟残るのみであった。一方、ブルガは 9 割近い住居によって所有さ れていた。テラスを持つ住居は 37 棟中 32 棟 $(86 \%)$ であった。カンプ と呼ばれる祭祀エリアには、イナンバレを内部に持ち、低い土壇上 に建てられ前面にテラスを持つ、茅莫の木造住宅バレが3棟とブル ガが7棟、かまやと穀倉が1棟ずつ配置されており、これらの建築

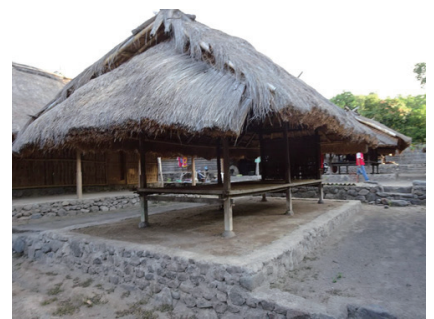

Photo 1 berugak ブルガ

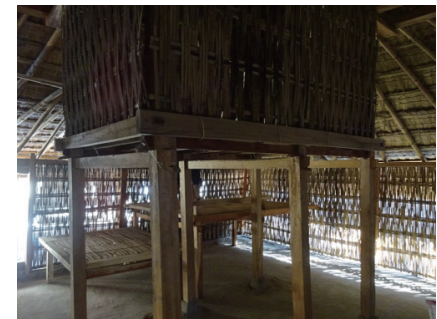

Photo 2 inen bale イナンバレ

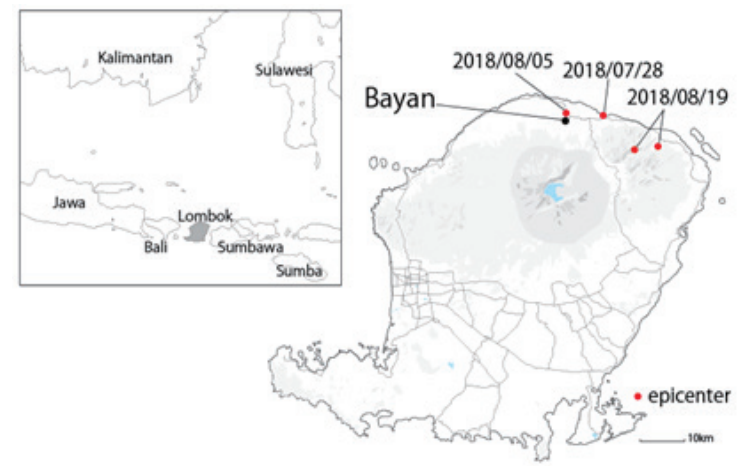

Fig. 1 Lombok earthquake and Bayan 2018ロンボク地震とバヤン

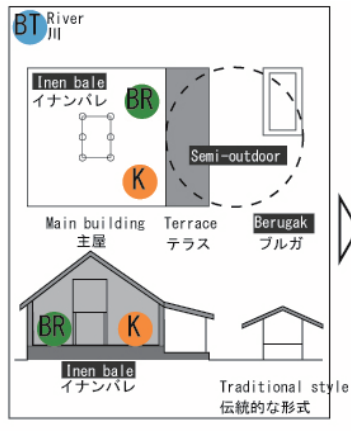

Fig. 2 Transition of the way of Iiving in Bayan
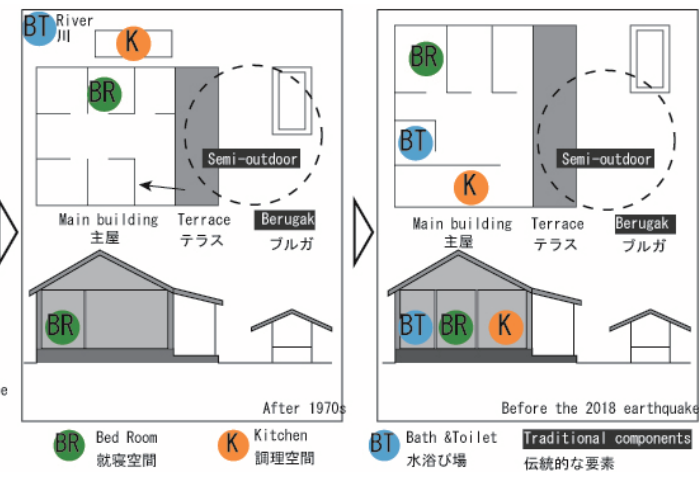

バヤンにおける住まい方の変遷注 5 
は、この地域の伝統的な形式を残すものと考えられる。一方、カン プ以外の地区の37棟のうちイナンバレを持つ6棟を除いた 31 棟は、 壁にモルタル・レンガ、屋根にトタン・スレート・瓦といった近代 的な材料を用いたものであり、建築物として伝統的とは言い難い。

伝統的な住居形式は、カンプで見られるようなイナンバレを内部 に持つ 1 室構成で、前面にテラスを持つ茅莫・竹網代の木造住宅で ある。この主屋とブルガとが対になって、南側に位置する聖山リン ジャニ山を意識し、リニアに配置される。東バヤン地区には、もと もとこの住居形式を持つものが多くを占めていたと考えられる。主 屋内部には、後ろ側に、就寝空間である露台が置かれるとともに、 地面に設けられたかまどが調理空間として備えられており、水浴び は近くを流れる川を使用していたと考えられる。

1990年代にはイナンバレを持つ形式は減少し、主屋に複数の個室 (寝室) を持つ形式が一般化していた。調理空間は、主屋外の付属 建物等に移行したものが7割を占めたが注 6$)$ 、水浴びは川がそのま ま使用されていた。2015年・2016年の調査では、イナンバレを持つ 形式はカンプ内では3棟そのまま残るが、その他の地区では6棟から 4 棟に減少していた。大きく変化したのは、水浴び場である。水道 が整備され3分の 1 の住居で主屋内に、3分の 2 の住居で付属建物とし て水浴び場が設けられていた。調理空間は、主屋内に設置するケー スが4割へと増えていた。

主屋は部材の変更やイナンバレの減少など大きく変化してきた。 また、ブルガの屋根材もトタン・スレートへと変化したが、ブルガ は大きく減少することなく維持され続けていた。バヤンでの伝統的 な住まい方は少しずつ変化をしているが、ブルガを利用した生活

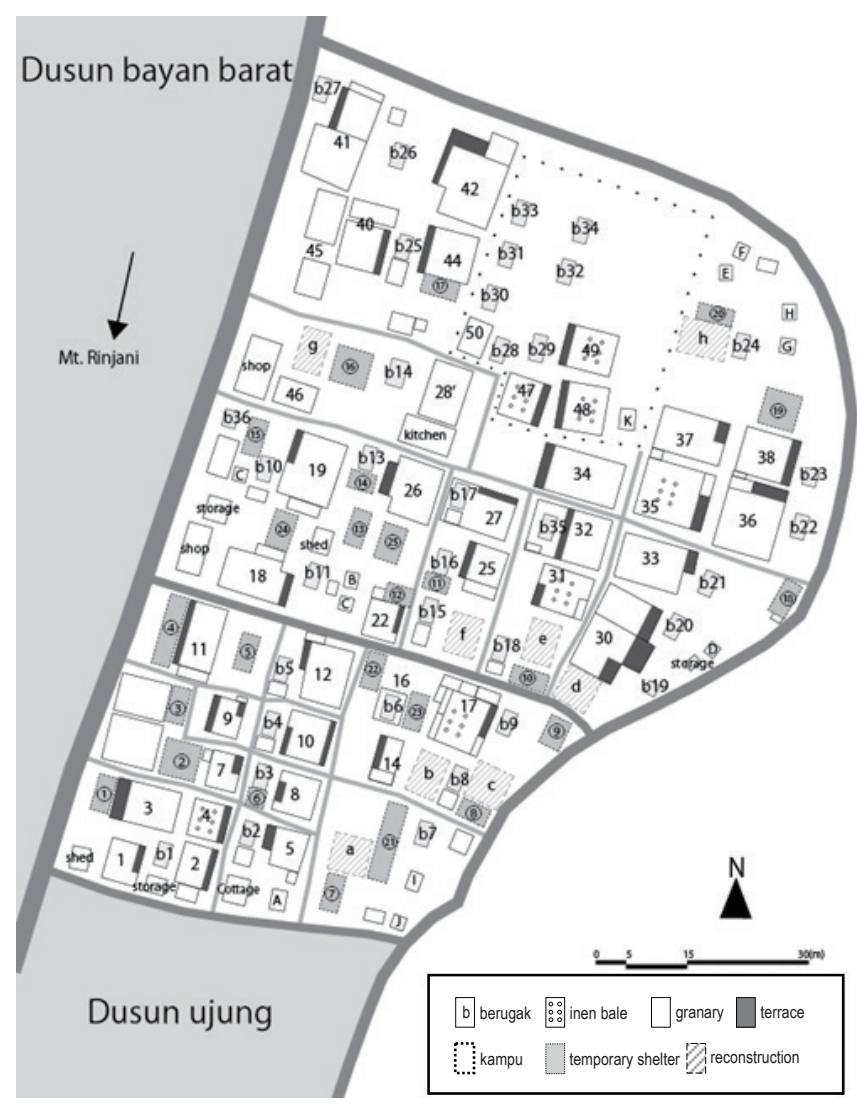

Fig. 3 One year (2019) after Bayan Timur from disaster 災害から 1 年後のバヤン
や、主屋一テラスーブルガの一体となった生活空間は災害前の時点 では残されていたことが分かる。

\section{3. バヤンにおける仮設住居の実態 \\ 3-1 集落の概要}

被災 1 年後の 2019 年 8 月調查時の東バヤンの配置図・復旧状況を Fig. 3に示す。仮設住居 (temporary she1ter) が建設されるととも に、恒久的な住宅再建 (reconstruction) も行われている。取り壊さ れた主屋は46棟中9棟である。被害の大きい主屋はほとんどが取り 壊されていた注7)。その跡地は、空き地や、仮設住居や政府や住民 による再建住居の敷地となっていた。イナンバレを持つ主屋やブル ガは元々被害がほとんどないため、すべてが取り壊されることなく 使用されていた。北側中央のカンプ内の伝統的住居も変わらず残さ れていた。

集落内には仮設住居が25棟設置されており、23棟がNPOである Yayasan Bumi Tangguhの提供で、2棟が住民により資材が集められ 自力で建てられた仮設住居であった。政府による再建住居が建設中 の段階で、調查時点では完成しているものは確認されなかった。政 府による再建住居は、調查時点では8棟であった。

\section{3-2 仮設住居の概要}

仮設住居は、亜鉛アルミニウムフレームを構造とし、外壁と内壁 は竹の網代を用いており、屋根は亜鉛アルミ板である（Photo 3)。

仮設住居の提供は被災から3か月後の2018年11月から行われ、住

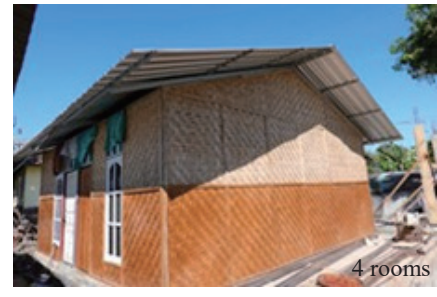

Photo 3 Temporary shelter from NPO

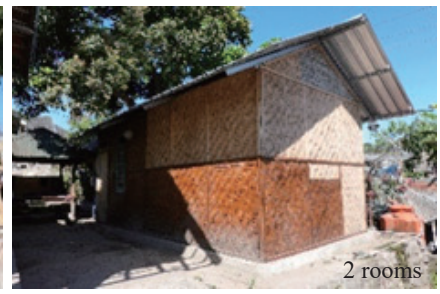

NPOが提供した仮設住居
Table 1 Spatial composition of temporary shelter 仮設住居の構成

\begin{tabular}{|c|c|c|c|c|c|c|c|c|}
\hline \multirow[b]{2}{*}{ No. } & \multirow{2}{*}{$\operatorname{size}(m)$} & \multirow{2}{*}{$\begin{array}{l}\text { Number } \\
\text { of rooms }\end{array}$} & \multicolumn{6}{|c|}{ function } \\
\hline & & & $\begin{array}{l}\text { bed } \\
\text { room }\end{array}$ & kitchen & toilet & living & $\begin{array}{c}\text { ware } \\
\text { house }\end{array}$ & $\begin{array}{l}\text { guest } \\
\text { room }\end{array}$ \\
\hline (1) & $3 \times 6$ & 2 & & 1 & & & 1 & \\
\hline (2) & $6 \times 6$ & 4 & 3 & & & 1 & & \\
\hline (3) & $3 \times 6$ & 2 & 1 & & & & 1 & \\
\hline (4) & $3 \times 11.5$ & 4 & 2 & 1 & & & 1 & \\
\hline (5) & $3 \times 6$ & 2 & 2 & & & & & \\
\hline (6) & $3 \times 3$ & 1 & 1 & & & & & \\
\hline (7) & $3 \times 6$ & 2 & 1 & & & 1 & & \\
\hline (8) & $3 \times 6$ & 2 & 1 & & & & & 1 \\
\hline (9) & $3 \times 6$ & 2 & 2 & & & & & \\
\hline (10) & $3 \times 6$ & 2 & 2 & & & & & \\
\hline (11) & $3 \times 4$ & 2 & & 1 & 1 & & & \\
\hline (12) & $3 \times 4.3$ & 2 & 1 & & & & 1 & \\
\hline (13) & $3 \times 6$ & 2 & 2 & & & & & \\
\hline (14) & $3 \times 4.3$ & 1 & 1 & & & & & \\
\hline (15) & $3 \times 6$ & 2 & 2 & & & & & \\
\hline (16) & $6 \times 6$ & 4 & 3 & & & 1 & & \\
\hline (17) & $3 \times 6$ & 2 & 2 & & & & & \\
\hline (18) & $3 \times 6$ & 2 & 2 & & & & & \\
\hline (19) & $6 \times 6$ & 4 & 3 & 1 & & & & \\
\hline (20) & $2.75 \times 6$ & 2 & 1 & & & & 1 & \\
\hline (21) & & & & - & & & & \\
\hline (22) & $3 \times 6$ & 2 & 2 & & & & & \\
\hline (23) & $3 \times 6$ & 2 & 1 & & & 1 & & \\
\hline (24) & $6 \times 4.7$ & 2 & 2 & & & & & \\
\hline
\end{tabular}


居の被害に関わらず仮設住居の提供は行われた。仮設住居の大きさ をTable1に示す。基本的には $3 \mathrm{~m} \times 3 \mathrm{~m}$ を基本単位とし、1室構成の場 合は $3 \mathrm{~m} \times 3 \mathrm{~m} 、 2$ 室構成の場合は $3 \mathrm{~m} \times 6 \mathrm{~m}$ 、4室構成の場合は $6 \mathrm{~m} \times 6 \mathrm{~m}$ と なっている。提供される仮設住居の大きさは地方自治体に正式に登 録されている世帯人数によって決まっていた。

設置場所は25棟のうち13棟が所有する主屋やブルガ周辺の空き地 に設置していた。7棟が主屋を取り壊し設置していた。5棟で所有す る付属建物を取り壊して設置していた。仮設住居を設置する際に場 所の確保のためにブルガを移動しているものが1件あった。元の敷 地から離れて設置されることはなく、元の敷地内に設置していた。

\section{3-3 仮設住居の使われ方}

平面図の実測が可能であった仮設住居の 23 棟で使われ方の分析を 行う（Table1）。仮設住居の構成は、1室構成が 2 棟、2室構成が 17 棟、4室構成が 4 棟に分類できる。いずれも入口前面にテラスを持つ ことはなく、外部から直接室内に入る形式である。仮設住居の平面 図例をFig. 4 示す。1室構成の場合、2棟とも寝室として利用して いる。2室構成の場合、9棟で2部屋とも寝室として利用している。6 棟で、1部屋を寝室として、残りの1部屋を倉庫(3棟) ・ 客室(1棟) ・ 居間 (2棟) としていた。2棟は、キッチンと倉庫、キッチンとトイ レ、としていた。4室構成の場合、3棟で3部屋を寝室として利用 し、残りの1部屋を居間または倉庫として利用している。1棟では、 寝室が2部屋、台所、倉庫が1部屋ずつであった。寝室を備える仮設 住居は21件 $(91 \%)$ で、寝室を備えない仮設住居は2件（9\%) である。 部屋数でみても、52部屋中 37 部屋が寝室で全体の $71 \%$ 占める。倉

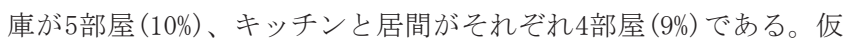
設住居は主に寝室として使われているが、寝室として利用しない世 帯では、倉庫、キッチン、居間として使われているのがわかる。

基本的には入り口が1つであるものが多いが、内部を壁で区切 り、それぞれに入り口を設けている仮設住居も確認できた。その場 合は、寝室とキッチンといった用途がそれぞれ違う場合や、世帯ご とに分かれて就寝するために寝室を分けている場合であった。

\section{4. 被災後 1 年間の居住環境の変化}

\section{4-1 生活空間の変化}

被災直後から被災 1 年後の住まい方の分析から地震の被害、復旧 仮設で建設された仮設住居の影響を明らかにする。住まい方におい ては様々な生活空間があるが、本研究では就寝空間、調理空間、水 浴び場に着目し注8)、さらに社会状況が変化する中でも残されてき た伝統的な生活空間要素（Fig. 2）であるブルガ、ブルガ・テラス 空間、ブルガ・テラス・主屋の関係が地震の被害、さらには仮設住 居の建設を受けてどのように変化するのかについて検討を行う。被 災後の生活空間をTable2に示す。

就寝空間は、仮設住居の供給によって大きく移行することがわか

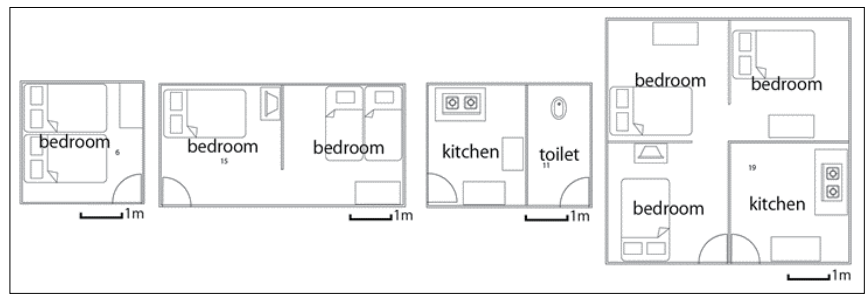

Fig. 4 Examples of Temporary Shelter Plan 仮設住居の使われ方の代表例
Table2 Living space after the earthquake 生活空間の変遷

\begin{tabular}{|c|c|c|c|c|c|c|c|c|c|}
\hline \multirow{2}{*}{$\begin{array}{l}\text { House } \\
\text { No. }\end{array}$} & \multirow[t]{2}{*}{$\begin{array}{l}\text { Ownership } \\
\text { 所有関係 }\end{array}$} & \multicolumn{2}{|c|}{$\begin{array}{l}\text { S1eeping } \\
\text { 就葠空間 }\end{array}$} & \multicolumn{3}{|c|}{$\begin{array}{l}\text { Bathing } \\
\text { 水浴び場 }\end{array}$} & \multicolumn{3}{|c|}{$\begin{array}{l}\text { Cooking } \\
\text { 調理空間 }\end{array}$} \\
\hline & & 2018 & 2019 & before & 2018 & 2019 & before & 2018 & 2019 \\
\hline 1 & \multirow{2}{*}{$\begin{array}{l}\text { No. } 1 \text { 、No. } 3 \text { 、 } \\
\text { B1 TS(1) }\end{array}$} & $B$ & $B$ & M & $E$ & $\mathrm{M}$ & M & $E$ & TS \\
\hline 3 & & B & B & M & E & M & M & $E$ & TS \\
\hline 2 & \multirow{2}{*}{ No. 2、No. 4、B2 } & M & M & A & A & A & E & $E$ & A \\
\hline 4 & & $\mathrm{M}, \mathrm{B}$ & M & A & A & $\mathrm{R}$ & A & A & A \\
\hline 5 & No. 5 & $\operatorname{Tr}$ & $\operatorname{Tr}$ & A & A & A & A & $\operatorname{Tr}$ & $\operatorname{Tr}$ \\
\hline 6 & (No. 6)、TS(2) & Tr, B & B, TS & M & A & A & M & $\operatorname{Tr}$ & A \\
\hline 7 & No. 7 & U & B, Tr & U & A & M & M & $E$ & $\operatorname{Tr}$ \\
\hline 8 & No. 8、B3、TS(6) & $\mathrm{T}$ & \begin{tabular}{|l|} 
TS \\
\end{tabular} & M & $R$ & $\mathrm{R}$ & $\mathrm{A}$ & $E$ & $\operatorname{Tr}$ \\
\hline 9 & No.9、TS(3) & - & M, TS & - & - & $\mathrm{R}$ & - & - & $E$ \\
\hline 10 & \multirow{2}{*}{ 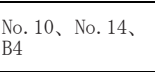 } & $\mathrm{S}, \mathrm{Tr}$ & \begin{tabular}{|l|} 
M \\
\end{tabular} & $\mathrm{U}$ & U & $\mathrm{A}$ & $\mathrm{s}$ & $\operatorname{Tr}$ & A \\
\hline 14 & & \multicolumn{8}{|c|}{ (Storage) } \\
\hline 11 & No.11、TS(4) & B, Tr & TS & M & A & $\mathrm{A}$ & M & $\operatorname{Tr}$ & TS \\
\hline 12 & No.12、B5 & $B$ & B & $\mathrm{A}$ & $\mathrm{A}$ & $\mathrm{A}$ & $\mathrm{A}$ & Tr & $\mathrm{Tr}$ \\
\hline 13 & $\begin{array}{l}\text { (No. 13), TS } \\
\text { (7), TS(21)、B7 }\end{array}$ & B & TS & A & $\mathrm{s}$ & $\mathrm{s}$ & $\mathrm{s}$ & E & TS \\
\hline 15 & $\begin{array}{l}(\text { No. 15) }, \text { B8 } \\
\text { TS(8) }\end{array}$ & M & TS & A & s & s & A & $\operatorname{Tr}$ & A \\
\hline 16 & \begin{tabular}{|l} 
No. 16$), B 6$, \\
TS(22, TS(23)
\end{tabular} & s & TS & A & $\mathrm{R}$ & s & E & E & E \\
\hline 17 & \begin{tabular}{|l|} 
No. $17 、$ B9,TS \\
9
\end{tabular} & U & TS & A & A & A & s & E & A \\
\hline 18 & $\begin{array}{l}\text { No. } 18, B 11 、 T S \\
\text { (24) }\end{array}$ & U & B, TS & U & U & A & U & U & A \\
\hline 19 & \multirow{2}{*}{$\begin{array}{l}\text { No. 19、 } \\
\text { (No. 20)、B10、 } \\
\text { TS(15) }\end{array}$} & $\mathrm{T}$ & M, TS & A & A & A & A & A & A \\
\hline 20 & & \multicolumn{8}{|c|}{ (Storage) } \\
\hline 21 & \multirow{2}{*}{$\begin{array}{l}\text { (No. 21) } \\
\text { No. 28、TS16、 } \\
\text { B14 }\end{array}$} & B & TS & A & $\mathrm{A}$ & A & $\mathrm{s}$ & E & $E$ \\
\hline 28 & & B & M & $\mathrm{s}$ & A & $\mathrm{A}$ & $\mathrm{s}$ & E & E \\
\hline 22 & $\begin{array}{l}\text { lo. 22, TS (12), } \\
\text { B12 }\end{array}$ & $\mathrm{M}, \mathrm{B}$ & TS & A & A & A & A & $\operatorname{Tr}$ & Tr \\
\hline 23 & $($ No. 23) 、B15 & $\mathrm{M}, \mathrm{B}$ & - & A & $\mathrm{R}$ & - & M & $\operatorname{Tr}$ & - \\
\hline 24 & \begin{tabular}{|l|l}
$($ No. 24$)$ & TS \\
$(13)$ & TS(25)
\end{tabular} & - & - & A & - & - & A & - & - \\
\hline 25 & $\begin{array}{l}\text { No. } 25, \text { B16、TS } \\
\text { (i1) }\end{array}$ & B & B & A & $\mathrm{R}$ & TS & A & $\operatorname{Tr}$ & TS \\
\hline 26 & $\frac{\text { No. } 26 、 B 13 、 T S}{(14)}$ & B & TS & A & A & A & A & E & E \\
\hline 27 & \multirow{2}{*}{$\begin{array}{l}\text { No. 27、No. 34、 } \\
\text { B17 }\end{array}$} & $\operatorname{Tr}$ & $\operatorname{Tr}$ & M & $\mathrm{U}$ & A & A & $E$ & M \\
\hline 34 & & M & $\operatorname{Tr}$ & M & M & $\mathrm{A}$ & M & $E$ & M \\
\hline 29 & $\begin{array}{l}\begin{array}{l}\text { (No. 29)、B18、 } \\
\text { TS(10) }\end{array} \\
\end{array}$ & B & TS & A & A & A & A & A & $\mathrm{A}$ \\
\hline 30 & $\begin{array}{l}\text { No. 30、B19、 } \\
\text { B20 }\end{array}$ & B, $T$ & B & M & $\mathrm{R}$ & $\mathrm{R}$ & A & E & $\mathrm{E}$ \\
\hline 31 & No. 31 & $\mathrm{~T}$ & $\mathrm{U}$ & $\mathrm{U}$ & s & $\mathrm{U}$ & $\mathrm{A}$ & $\mathrm{U}$ & $\mathrm{U}$ \\
\hline 32 & No. 32、B35 & B, Tr & B, Tr & $\mathrm{A}$ & $\mathrm{A}$ & A & M & E & M \\
\hline 33 & 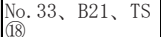 & $\mathrm{T}$ & TS & A & $\mathrm{R}$ & A & M & $\operatorname{Tr}$ & M \\
\hline 35 & \multirow{3}{*}{$\begin{array}{l}\text { No. 35, No. 37, } \\
\text { (No. 39)、B24, } \\
\text { TS(20) }\end{array}$} & - & - & - & - & - & - & - & - \\
\hline 37 & & $\mathrm{~T}$ & TS & A & $\mathrm{s}$ & $\mathrm{s}$ & - & $E$ & $E$ \\
\hline 39 & & $\mathrm{~T}$ & TS & M & $\mathrm{s}$ & $\mathrm{s}$ & M & $E$ & $E$ \\
\hline 36 & \multirow{2}{*}{$\begin{array}{l}\text { No. } 36 \text {, No. } 38 \\
\text { B22, B23、TS(19) }\end{array}$} & $\mathrm{B}, \mathrm{T}$ & TS & A & $\mathrm{R}$ & $\mathrm{R}$ & M & $\mathrm{A}$ & TS \\
\hline 38 & & $B$ & TS & $\mathrm{A}$ & $\mathrm{R}$ & $R$ & M & $\mathrm{A}$ & A \\
\hline 40 & \multirow{2}{*}{$\begin{array}{l}\text { No. } 40 \text { 、No. } 44 \text { 、 } \\
\text { B25、TS(17) }\end{array}$} & $\operatorname{Tr}$ & M & A & $\mathrm{A}$ & A & A & A & A \\
\hline 44 & & $\operatorname{Tr}$ & M, TS & $\mathrm{A}$ & $\mathrm{A}$ & $\mathrm{A}$ & $\mathrm{A}$ & $\mathrm{A}$ & $\mathrm{A}$ \\
\hline 41 & No. $41 、$ B27 & - & M & M & - & M & M & - & $\operatorname{Tr}$ \\
\hline 42 & \multirow{2}{*}{$\begin{array}{l}\text { No. } 42 \text {, } \\
\text { (No. 43)、B26 }\end{array}$} & B & M & M & A & A & M & $\operatorname{Tr}$ & M \\
\hline 43 & & B & M & M & A & A & M & $\operatorname{Tr}$ & M \\
\hline
\end{tabular}

B:Berugak, Tr:Terrace, T:Tent, M:Main building, TS:Temporary Shelter, A:Attached building, R:River, S:Separate building, E:Exterior space, U:Unknown

Table3 Transition Table4 Transition of Table5 Transition of of Sleeping space Bathing space Cooking space

\begin{tabular}{|c|c|c|c|c|c|c|c|c|c|c|}
\hline \multirow{3}{*}{ M 主屋 } & \multicolumn{2}{|c|}{ sleeping 就寝 } & & \multicolumn{3}{|c|}{ bathing 水浴び } & & \multicolumn{3}{|c|}{ Cooking 調理 } \\
\hline & \multirow{2}{*}{$\begin{array}{r}2018 \\
(14 \%)\end{array}$} & \multirow{2}{*}{\begin{tabular}{r|}
2019 \\
11 \\
$(24 \%)$
\end{tabular}} & \multirow{3}{*}{\begin{tabular}{||l} 
\\
$\mathrm{M}$ 主屋
\end{tabular}} & \multirow{2}{*}{ before } & \multirow{2}{*}{2018} & \multirow{2}{*}{2019} & \multirow{2}{*}{ M 主屋 } & \multirow{2}{*}{\begin{tabular}{|r|} 
Before \\
16 \\
$(42 \%)$ \\
\end{tabular}} & \multirow{2}{*}{$\frac{2018}{0(0 \%)}$} & \multirow{2}{*}{$\begin{array}{r}2019 \\
6 \\
(16 \%)\end{array}$} \\
\hline & & & & & & & & & & \\
\hline S別棟 & $1(2 \%)$ & $0(0 \%)$ & & $(33 \%)$ & $1(3 \%)$ & $(11 \%)$ & S 別棟 & $5(13 \%)$ & $0(0 \%)$ & $0(0 \%)$ \\
\hline $\begin{array}{l}\text { TS } \\
\text { 仮設住居 }\end{array}$ & - & $\begin{array}{r}20 \\
(44 \%) \\
\end{array}$ & S 別棟 & $1(3 \%)$ & $(20 \%)$ & $\begin{array}{r}5 \\
(13 \%) \\
\end{array}$ & 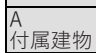 & $\begin{array}{r}15 \\
(39 \%) \\
\end{array}$ & $(19 \%)$ & $\begin{array}{r}12 \\
(32 \%)\end{array}$ \\
\hline $\operatorname{Tr}$ テラス & $\begin{array}{r}8 \\
(19 \%)\end{array}$ & $\begin{array}{r}5 \\
(11 \%)\end{array}$ & A 付属 & $\begin{array}{r}23 \\
(64 \%) \\
\end{array}$ & $\begin{array}{r}19 \\
(54 \%) \\
\end{array}$ & $\begin{array}{r}22 \\
(58 \%) \\
\end{array}$ & \begin{tabular}{|l|} 
TS \\
仮設住居
\end{tabular} & - & - & $\begin{array}{r}6 \\
(16 \%)\end{array}$ \\
\hline B ブルガ & $\begin{array}{r}20 \\
(48 \%) \\
\end{array}$ & $\begin{array}{r}9 \\
(20 \%) \\
\end{array}$ & \begin{tabular}{|l|} 
TS \\
仮設住居 \\
至
\end{tabular} & - & - & $1(3 \%)$ & $\begin{array}{l}\text { Tr } \\
\text { テラス }\end{array}$ & $0(0 \%)$ & $\begin{array}{r}12 \\
(33 \%) \\
\end{array}$ & $\begin{array}{r}6 \\
(16 \%) \\
\end{array}$ \\
\hline Tテント & $\begin{array}{r}7 \\
(17 \%) \\
\end{array}$ & $0(0 \%)$ & $R 川$ & $0(0 \%)$ & $\begin{array}{r}8 \\
(23 \%) \\
\end{array}$ & $\begin{array}{r}6 \\
(16 \%) \\
\end{array}$ & E 外部 & $2(5 \%)$ & $\begin{array}{r}17 \\
(47 \%) \\
\end{array}$ & $\begin{array}{r}8 \\
(21 \%) \\
\end{array}$ \\
\hline
\end{tabular}

M:Main building, S:Separate building, TS:Temporary Shelter,
B:Berugak, T:Tent, A:Attached building, R:River, E: Exterior space 
る（Table3）。地震直後は、建物内部に就寝空間を設けるケース は、全体の16\%で、ブルガ、テラス、テントといった屋外空間は8割 を超える。中でもブルガを活用するケースは約半数 (48\%) を占め ている。 1 年後には、仮設住居が $44 \%$ 占める。一方で、3割のケー スで、テラス・ブルガといった屋外空間が使われている点も興味深 い。行政の支援による再建住宅の供給の方向性が明確ではなく、再 建は進んでおらず、そのため、主屋での就寝は4分の1に止まってお り、それもほとんどが従前の建物を補強して使用するケースであ る。

水浴び場は、地震前は 3 分の 1 が主屋内に設置、3分の 2 が主屋に併 設されるかたちで設置されていた（Table4）。地震直後は主屋内を 利用するケースはわずか 1 件のみで、付属建物を利用するケースが 半数近く見られた。水浴びという行為自体は、さほど長時間に渡る ものではなく、水浴び場自体も壁に囲まれた空間であるものの、ト タンや波板スレートといった簡易な屋根がかかるものが多く、従前 のものをそのまま使用したケースが多い。壁が倒壊するなどして使 用不可となった場合は、敷地内に簡易な目隠しを作った水浴び場

(別棟) を設けたり $(20 \%)$ 、近くの川で水浴びをするケースが見ら れた $(23 \%)$ 。1年後もさほど大きな変化は見られず、依然と川を利用 したり $(16 \%)$ 、別棟利用 (13\%) がある一定数占めている点が興味深 い。

伝統的に、水浴びは住居内や住居近傍でも行われておらず、川や 集落脇の茂みで行われていたものであり、積極的に住居内部に戻そ うとする意思は働きにくいと考えられる。

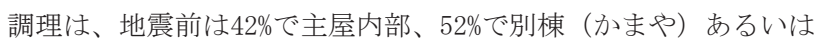
付属建物で行っていた（Table5）。地震直後は、半数近くで外部で 行われている。小型のプロパンボンベとコンロを住居前あるいはブ ルガ脇の空きスペースに設置し、そこで調理を行う形式である。火 を扱うためか主屋や別棟での利用は皆無であり、テラスと外部をあ

Table6 Relation between Sleeping space and Temporary Shelter

\begin{tabular}{|c|c|c|c|c|}
\hline & \multicolumn{2}{|c|}{ with Temporary Shelter } & \multicolumn{2}{|c|}{ without Temporary Shelter } \\
\hline & 2018 & 2019 & 2018 & 2019 \\
\hline $\mathrm{M}$ 主屋 & $2(8 \%)$ & $4(14 \%)$ & $4(24 \%)$ & $7(64 \%)$ \\
\hline$S$ 別棟 & $1(4 \%)$ & $0(0 \%)$ & $0(0 \%)$ & $0(0 \%)$ \\
\hline TS 仮設住居 & - & $20(69 \%)$ & - & $0(0 \%)$ \\
\hline Tr テラス & $3(12 \%)$ & $0(0 \%)$ & $5(29 \%)$ & $0(0 \%)$ \\
\hline B ブルガ & $13(52 \%)$ & $5(17 \%)$ & 7(41\%) & $4(36 \%)$ \\
\hline T テント & $6(24 \%)$ & $0(0 \%)$ & $1(6 \%)$ & $0(0 \%)$ \\
\hline
\end{tabular}

M:Main building, S:Separate building, TS:Temporary Shelter, Tr:Terrace, B:Berugak, T:Tent

Table7 Relation between Cooking space and Temporary Shelter

\begin{tabular}{|l|l|l|l|l|l|l|}
\hline \multirow{2}{*}{} & \multicolumn{3}{|c|}{ with Temmporary Shelter } & \multicolumn{3}{|c|}{ without Temporary Shelter } \\
\cline { 2 - 7 } & \multicolumn{1}{|c|}{ Before } & \multicolumn{1}{|c|}{2018} & \multicolumn{1}{|c|}{2019} & \multicolumn{1}{|c|}{ Before } & \multicolumn{1}{|c|}{2018} & \multicolumn{1}{c|}{2019} \\
\hline $\mathrm{M}$ 主屋 & $8(36 \%)$ & $0(0 \%)$ & $1(4 \%)$ & $8(50 \%)$ & $0(0 \%)$ & $5(36 \%)$ \\
\hline S 別棟 & $4(18 \%)$ & $0(0 \%)$ & $0(0 \%)$ & $1(6 \%)$ & $0(0 \%)$ & $0(0 \%)$ \\
\hline $\mathrm{A}$ 付属建物 & $9(41 \%)$ & $5(23 \%)$ & $8(33 \%)$ & $6(38 \%)$ & $2(14 \%)$ & $4(29 \%)$ \\
\hline $\mathrm{TS}$ 仮設住居 & - & - & $6(25 \%)$ & - & - & $0(0 \%)$ \\
\hline $\mathrm{Tr}$ テラス & $0(0 \%)$ & $6(27 \%)$ & $2(8 \%)$ & $0(0 \%)$ & $6(43 \%)$ & $4(29 \%)$ \\
\hline E 外部 & $1(5 \%)$ & $11(50 \%)$ & $7(29 \%)$ & $1(6 \%)$ & $6(43 \%)$ & $1(7 \%)$ \\
\hline
\end{tabular}

M:Main building, S: Separate building, A:Attached building, TS:Temporary Shelter, M:Main building, S:Separate
Tr:Terrace, E:Exterior space

Table8 Transition of Space utilization at Berugak and Terrace

\begin{tabular}{|l|r|r|r|r|}
\hline \multirow{2}{*}{} & \multicolumn{2}{|c|}{ Berugak ブルガ } & \multicolumn{2}{c|}{ Terrace テラス } \\
\cline { 2 - 5 } & 2018 & 2019 & 2018 & \multicolumn{1}{c|}{2019} \\
\hline Sleeping 就寝 & $17(61 \%)$ & $7(25 \%)$ & $9(28 \%)$ & $5(16 \%)$ \\
\hline Cooking 調理 & - & - & $10(32 \%)$ & $5(16 \%)$ \\
\hline open space & $11(39 \%)$ & $21(75 \%)$ & $17(53 \%)$ & $24(75 \%)$ \\
\hline Total & \multicolumn{4}{|r}{} \\
\hline
\end{tabular}

わせると 8 割を占めている。1年後には、テラス・外部で $37 \%$ 占め るが、その他の6割は室内（主屋・付属建物・仮設住居）に戻って いる。

就寝・水浴び・調理の3つの行為に関して、1年後の室内利用の割 合を見ると、いずれも7割から8割を占めていることがわかる。就寝 については、仮設住居が室内利用 31 件のうちの 20 件を占めており、 大きな役割を果たしていることがわかる。調理に関しても室内利用 24 件中の6件を仮設住居が占めており、決して無視できない割合を 示している。

仮設住居の影響による生活空間の変化が考えられる就寝と調理に ついて、仮設住居を与えられた世帯と与えられていない世帯の比較 を行う（Table6、Table7）。

就寝に関して仮設住居を所有する世帯の住居では、7割で仮設住

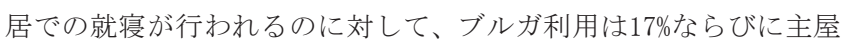
利用は14\%であった。仮設住居を所有しない世帯の住居と比較する とその違いは顕著である。ブルガ利用は $36 \%$ 、主屋利用は $64 \%$ であ り、ブルガの利用率は半分程度であることがわかる。また室内空間 での就寝欲求を、仮設住居を所有しない住居では、主屋が満たして いることがこの数值から読み取れる。

調理に関しては、仮設住居ありと仮設住居なしでは従前並びに地 震直後の数值にもともとばらつきが見られるが、それでも仮設住居 なしでは、1年後に主屋に調理空間を設ける割合が $36 \%$ を示してお り、仮設住居ありの $4 \%$ と比較して、顕著な違いを見せている。テラ ス並びに外部の值が互いに大きく異なるが、これはともに外部空間 での調理空間の設置を示しており、合計するとともに $36 \%$ （仮設な し）と $37 \%$ (仮設あり）となり、大きな違いは示さない。付属建物 の割合も、29\%（仮設なし）と33\%（仮設あり）とほぼ同じことから 考えると、仮設住居の提供されないことが主屋での調理の要因に なっていると言える。

つまり、仮設住居の供給は、寝室の提供に寄与することで、ブル ガの就寝空間利用の減退を誘引する。ブルガは、本来の団欒空間を 始めとした多目的空間へと戻っていくことになる。また、これらの データから、仮設住居を供給しなければ、就寝空間並びに調理空間 を主屋へ戻すことに影響するといえ、政府の経済的支援や住宅支援 が不十分な状態では、地震によって多かれ少なかれダメージを受け た住宅を使用せざるをえない状態を、少ないながらも加速させてい ると言える。

\section{4-2 ブルガ、テラスの変化}

被災後に伝統的な居住空間であるブルガやテラスがどのように使 われていたのかを分析する。被災直後、被災 1 年後のブルガ・テラ スの用途をTable8に示す。被災直後はカンプ内のブルガを除いた 28 棟のブルガ中 17 棟 $(61 \%)$ でブルガに寝具を置くなどして就寝空間と して利用していた。被災 1 年後には7棟、4分の1に減っていた。

また、テラス空間は32棟で確認できたが、被災直後には、その内 3割弱が就寝空間として使われ、3割強が調理空間として使われてい た。重複して使われるものもあるので、まったくオープンな空間と して残されていたテラスは5割強であった。それが被災 1 年後には、 就寝・調理ともに半分に減り、元々のテラス空間の状態に戻ってい るものが75\%であった。

必ずしも十分な量のデータではないが、このデータから言えるの 


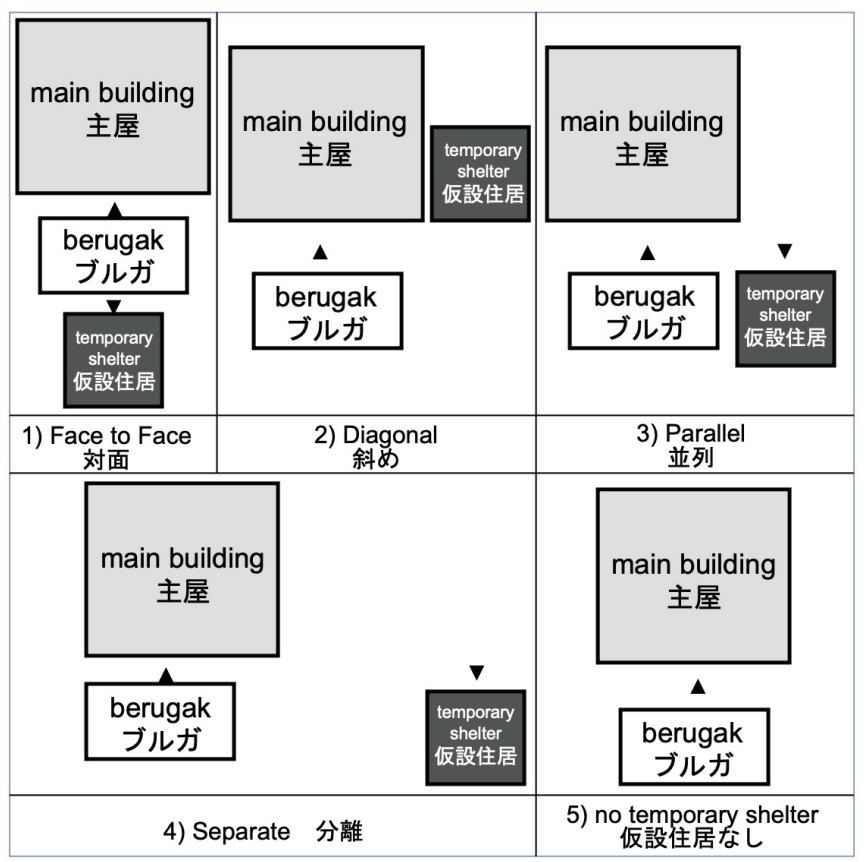

Fig. 5 Position among main building, berugak and temporary shelter ブルガと仮設住居の関係性

は、被災直後の非常時においては、ブルガの方がテラスよりも占有 される率が高いということである。また、ブルガは高床空間、テラ スは地床空間であるため、ブルガは就寝空間としてのみ使われる が、テラスは、ベッドやマットが持ち込まれ就寝空間として使われ るとともに、コンロやプロパンが持ち込まれ調理空間として使われ る。時間とともに、元の空間利用に戻っていくが、仮設住居のみて 再建住宅が建設されていないためか、 1 年では、非常時の利用がそ のまま約半数で継続されている。ブルガ・テラスといった住居に付 設する半屋外の空間は、住民にとって日常生活における重要な空間 であり、生活再建が進むにつれて元の使い方に戻っていくことがわ かる。

\section{4-3 ブルガ・主屋・仮設住居の関係}

Fig. 2に示す通り、伝統的な住まい方では東バヤン地区では主屋 とはテラスを挟む形でブルガと対面に配置されていた。被災 1 年後 には多くの世帯で生活を仮設住居に移していた。被災1年後のブル ガと主屋（テラスを含む）、仮設住居の位置関係から、生活動線の 変化を分析する。

カンプ内のブルガ等注9) を除いた28のブルガをみると、被災当初 は寸べてのブルガが主屋と対面に配置されていた。被災1年後の主 屋とブルガ、仮設住居の関係を整理すると5つに分類できた (Fig. 5)。Table9に示すように分析対象とした28ブルガのうち、1) ブルガと仮設住居が対面であるのが 4 事例、2)ブルガと仮設住居が 斜め向かい合わせであるのが 8 事例、3) 仮設住居とブルガが並列で あるのが2事例、4)仮設住居とブルガが分離しているのが4事例、5) 仮設住居を所持していないが10事例であった。

被災1年後には、主屋は37棟中8棟が取り壊されていた。再建住宅 の建設は、その時点ではまだ始まろうとしていた時期であったが、 既にブルガb7に関しては、再建住宅の敷地とブルガとの間に仮設住 宅が配置されており、仮設住居が仮設とはならずその後も残された 場合、主屋（再建住宅）とブルガの関係は仮設住居によって分断さ
Table9 Relation between berugak and nearby buildings

\begin{tabular}{|c|c|c|c|c|c|c|c|c|c|c|c|}
\hline \multicolumn{3}{|c|}{ Number } & \multicolumn{2}{|c|}{ Sleeping } & \multicolumn{3}{|c|}{ Bathing } & \multicolumn{3}{|c|}{ Cooking } & \multirow{2}{*}{$\begin{array}{c}\text { Position Type } \\
\text { ブルガと仮設の位置関係 }\end{array}$} \\
\hline B & $\mathrm{H}$ & TS & 2018 & 2019 & \begin{tabular}{|c|}
$b e-$ \\
fore
\end{tabular} & 2018 & 2019 & $\begin{array}{l}\text { be- } \\
\text { fore }\end{array}$ & 2018 & 2019 & \\
\hline $\mathrm{b} 1$ & 1,3 & (1) & 웅 & ? & & & & & $\square$ & & 4) Separate 分離 \\
\hline b2 & 2,4 & - & $\bullet$ & & & & & घ & - & - & $\begin{array}{l}\text { 5) No termporary } \\
\text { shelter }\end{array}$ \\
\hline b3 & 8 & (6) & & & & & & 口 & & & 3) Parallel 並列 \\
\hline b4 & 10,14 & - & & & & & - & & & $\square$ & $\begin{array}{l}\text { 5) No termporary } \\
\text { shelter }\end{array}$ \\
\hline b5 & 12 & - & $\bullet$ & $\bullet$ & & & - & $\mathbf{\square}$ & & & $\begin{array}{l}\text { 5) No termporary } \\
\text { shelter }\end{array}$ \\
\hline \multirow{2}{*}{ b6 } & \multirow{2}{*}{16} & (22) & & & \multirow{2}{*}{$\square$} & & & \multirow{2}{*}{$\square$} & \multirow{2}{*}{$\square$} & \multirow{2}{*}{$\square$} & 2) Diagonal 斜め \\
\hline & & (23) & & & & & & & & & 1) Face to Face 対面 \\
\hline \multirow{2}{*}{ b7 } & \multirow{2}{*}{$13^{*}$} & (7) & \multirow{2}{*}{ ○ } & & & \multirow{2}{*}{$\square$} & & \multirow{2}{*}{ - } & & \multicolumn{2}{|r|}{ 4) Separate 分離 } \\
\hline & & (21) & & & & & & & & & \multirow{2}{*}{$\begin{array}{l}\text { 1) Face to Face 対面 } \\
\text { 2) Diagonal 斜め }\end{array}$} \\
\hline b8 & $15^{*}$ & (8) & 0 & & & & $\square$ & & & $\square$ & \\
\hline b9 & 17 & (9) & $U$ & & & & & & & & 1) Face to Face 対面 \\
\hline b10 & $19,20 *$ & (15) & & & & & & & & & 2) Diagonal 斜め \\
\hline b11 & 18 & (24) & $U$ & 운 & & & & & & & 2) Diagonal 斜め \\
\hline${ }_{*}^{b} 12$ & 22 & (12) & $\bullet$ & & & & & & & & - \\
\hline $\mathrm{b} 13$ & 26 & (14) & 0 & & $\boldsymbol{\square}$ & & & $\mathbf{\square}$ & $\square$ & $\square$ & 3) Parallel 並列 \\
\hline b14 & $21 *, 28$ & (16) & 운 & & & & & & & & 1) Face to Face 対面 \\
\hline b15 & $23^{*}$ & - & - & & & & & & & & $\begin{array}{l}\text { 5) No termporary } \\
\text { shelter }\end{array}$ \\
\hline b16 & 25 & (11) & 우 & - & $\square$ & & & $\mathbf{\square}$ & & & 3) Parallel 並列 \\
\hline b17 & 27,34 & - & & & & & & घ & & & $\begin{array}{l}\text { 5) No termporary } \\
\text { shelter }\end{array}$ \\
\hline b18 & $29 *$ & (10) & ○ & & - & $\mathbf{\square}$ & $\mathbf{\square}$ & $\mathbf{E}$ & $\square$ & $\square \mathbf{\square}$ & 2) Diagonal 斜め \\
\hline b19 & 30 & - & $\bullet$ & $\bullet$ & & & & & & & $\begin{array}{l}\text { 5) No termporary } \\
\text { shelter }\end{array}$ \\
\hline b20 & 30 & - & • & $\bullet$ & & & & $\mathbf{\square}$ & & & $\begin{array}{l}\text { 5) No termporary } \\
\text { shelter }\end{array}$ \\
\hline b21 & 33 & (18) & & & & & & & & & 4) Separate 分離 \\
\hline b22 & & & 0 & & & & & & & & 4) Separate 分離 \\
\hline b23 & 36,38 & (19) & - & & & & & & 口 & $\mathbf{\square}$ & 2) Diagonal 斜め \\
\hline b24 & $\begin{array}{l}35,37 \\
39 *\end{array}$ & (20) & & & & & & & $\square$ & $\square$ & 2) Diagonal 斜め \\
\hline b25 & 40,44 & (17) & & & $\boldsymbol{\square}$ & $\mathbf{\square}$ & $\mathbf{\square}$ & $\mathbf{\square}$ & 口 & 口 & 2) Diagonal 斜め \\
\hline b26 & $42,43^{*}$ & - & $\bullet$ & & & & & & & & $\begin{array}{l}\text { 5) No termporary } \\
\text { shelter }\end{array}$ \\
\hline b27 & 41 & - & & & & & & & & & $\begin{array}{l}\text { 5) No termporary } \\
\text { shelter }\end{array}$ \\
\hline b35 & 32 & - & - & $\bullet$ & & & & & $\square$ & & $\begin{array}{l}\text { 5) No termporary } \\
\text { shelter }\end{array}$ \\
\hline
\end{tabular}
B:Berugak, H:House, TS:Temporary Shelter, U:Unknown 0 :observed at Berugak,
$\mathbf{\square}$ :observed as attached building of Berugak, $\square$ :observed next to Berugak, *:

れることになる。 $\mathrm{NGO}$ は仮設住居を一時的なものとして供給した が、その後の除去については強制力を持たず、どのように使われる かは不透明である。

分析した28事例において全て災害前からの伝統的な住まい方であ るブルガと主屋（従前の主屋）が対面する形式は維持されているこ とが分かる。一方、時限的なものと想定されたとはいえ、居住空間 として供給された仮設住居は、前面にテラスを持たず、ブルガと主 屋がテラスを挟み込む形式を摇るがすものとして存在している。ブ ルガと仮設住居の関係は、1) 対面の 4 件ではブルガと仮設住居が対 面関係にあるが、3)並列と4) 分離の6件でブルガとの対面関係は構 築されておらず、寝室として使われているが伝統的な主屋・ブルガ の関係とはなっていない。2)斜めの8件においても、直接的な対面 関係になく、ブルガ・仮設住居をともにもつケースのうち約8割 (18 件中14件)で対面する形式になっていない。

\section{5.まとめ}

本研究では災害から1年が経過した被災地バヤンにおいて、地震 の被害、仮設住居の建設が伝統的な住まい方に与える影響について 検討を行い、災害直後大きく変化した住まい方が、一見異質に見え る仮設住居が建設された後、徐々に伝統的な住まい方に戻っていく 姿を明らかにすることができた。

具体的な成果は以下の通りである。 
1) 被災直後は、地震による壁の倒壊の恐怖からブルガやテラスと いった主屋以外の被害の恐れが少ない場所へ生活空間を移動した。 仮設住居の提供を受けた段階で、ブルガやテラスで行われていた就 寝や調理の行為を仮設住居内に移動させる世帯が多くみられた。 2)ブルガやテラスは、被災直後に就寝空間や調理空間として利用さ れ、非常時の生活空間として重要な機能を果たすが、その後、仮設 住居の供給などを通して、日常的な空間利用に徐々に戻っていく。 3) 仮設住居が建設されても主屋とブルガの関係は維持される。仮設 住居は一時的な生活空間としての役割を果たすが、前面にテラスも 保持しておらず、ブルガとの配置関係においても伝統的な居住空間 の役割を果たすものではなく、継続的に使用されるとすれば注意が 必要である。

本調査時から政府が提供する再建住宅が開始されており、元の主 屋、ブルガ、仮設住居、そして新築される再建住宅の関係について 今後継続的調查を実施し、伝統的な住まい方の変化並びに、今後の 災害後の住宅供給のあり方について検討を行っていきたい。

\section{謝辞}

本論文は、JSPS科学研究費補助金基盤研究 (B)「インドネシアに おける歴史的環境の復興・継承に向けた計画手法」（JP19H02326）に よる研究成果である。

注

注1)インドネシア・ロンボク島バヤンについては、脇田・布野らのグループ が1991年から継続的に調査を行っており、災害直前についても2015、2016 年に調査を行っている。

注2) 調查メンバーは、本論文の共同執筆者である有年秀介、牧紀男、脇田祥 尚、張漢賢、グレゴリアス・アグン、笹谷満の他、松本友惟（近畿大学大 学院修了）、福田絋太、川端歩実、松尾銀二（近畿大学建築学部卒業）で ある。

注3) 大きな被害を受けた家屋には5,000万ルピア、中程度に被害を受けた家 屋には2, 500万ルピア、軽度に被害を受けた家屋には 1,000 万ルピアであっ た。

注4) 本論では、ブルガも住居の一部として捉え、ブルガと区別するため、主 屋という語句を用いる。他に、母家・母屋という語句があるが、この地区 の伝統的な住居の内部に設けられるイナンバレは、家の母（イナンは母、

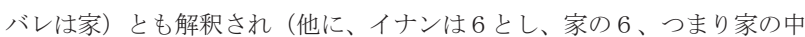
の 6 本の柱を指すとも言われる）、母家・母屋といら語句を用いると、イ ナンバレを持つ住居のみに対する呼称と混乱しかねないので、母という語 の使用を避け、主屋を用いる。

注5) 1992年から1994年にかけて行った調査によって得られた成果は図中では After 1970sとして表記した。近代的な材料の流通により住居の建替えが 促進され、その際、調理空間が外部に設けられるようになったと考えられ るが、これらの変化はインドネシアの他地域の事例等から想定すると 1970 年代に起こったと考えている。

注6）調理空間は37棟中、主屋内に位置するものが11棟 (30\%)、主屋・ブルガ の付属建物としてあるものが 21 棟 $(57 \%)$ 、別棟としてかまやを持つものが 5 棟 $(14 \%)$ であった。主屋内の11棟のうち4棟はイナンバレを持つ形式であ るため、新たに建て替えられたもので内部に持つものは7棟(19\&)である。

注7）各住居の被害状況をEMS-98を用いて5段階評価で判定（文献7)）してい るが、最も被害度の大きいG5で4棟中3棟、G4で8棟中6棟が除去されてい る。

注8)就寝、調理、水浴びは基本的欲求の最低次である生理的欲求の睡眠、食 事、排泄に対応している。生活再建の際に、まずこれらの欲求を満たす必 要があるため、これらの生活行為が行われる空間に着目する必要がある。 注9）日常的な生活空間でのブルガの実態を分析対象とするため、聖域である カンプ並びに幹線道路沿いのブルガは対象外とした。

\section{参考文献}

1) Maeda, M. , Nakagawa, Y., Yamada, K., Funo, S. : Consideration realities and issues of settlements in south west cost of Sri Lanka after the Sumatra earthquake and Indian ocean tsunami in 2004: from the view of continuation from the usual living environment, Journal of Architecture and Planning (Transactions of AIJ), Vol.72, No.614, pp. 183-190, 2007.4 (in Japanese) 前田 昌弘, 中川 雄輔, 山田 協太, 布野 修司:インド洋スマトラ島沖地震津 波後のスリランカ南西沿岸居住地における復興の実態と問題点に関する考 察: 平常時の居住環境との連続性に着目して, 日本建築学会計画系論文 集, 72巻, 614号, pp. 183-190, 2007.4

2) Yamazaki, Y., Tanaka, T., Yamaguchi,H., Shigemura, T., Hokugo, A. The influence of traditional building arrangement and site composition on rebuilding dwelling environments: in the case of Plembutan sub-village as an effected area of the 2006 central Java earthquake, Journal of Architecture and Planning (Transactions of AIJ), Vol. 74, No. 639, pp. 1075-1083, 2009. 5 (in Japanese) 山崎 義人, 田中 貴宏, 山口 秀文, 重村 力, 北後 明彦: 伝統的な建物配置や 敷地構成の居住環境の再建への影響－2006年ジャワ島中部地震被災地であ るプレンブタン集落を事例として一, 日本建築学会計画系論文集, 74巻, 639 号, pp. 1075-1083, 2009.5

3) Hayashi, D., Hokugo, A., Shigemura, T. : A study on housing reconstruction after 2006 Central Java earthquake, Report of Research Center for Urban Safety and Security, Kobe University. No. 12, pp. 155-162, 2008 (in Japanese)

林 大造, 北後 明彦, 重村 力:2006年ジャワ島中部地震における住宅復興の あり方, 神戸大学都市安全研究センター研究報告, 12巻, pp. 155-162, 2008

4) Wakita, Y., Funo, S., Maki, N., Aoki, A. : Space organization of the settlement in desa Bayan in Lombok island, Indonesia, Journal of Architecture, Planning and Environmental Engineering (Transactions of AIJ), Vol.60, No.478, pp.61-68, 1995.12 (in Japa nese)

脇田 祥尚, 布野 修司, 牧 紀男, 青井 哲人:デサ・バヤン(インドネシア ロンボク島) における住居集落の空間構成, 日本建築学会計画系論文集, 60 巻, 478号, pp. 61-68, 1995. 12

5) Sasatani, M., Wakita, Y. : Residential planning configuration of Gubuk Tengah in Lombok island (Indonesia), Summaries of Technical Papers of Annual Meeting, Architectural Institute of $\mathrm{Ja}^{-}$ pan, Architectural Planning and Design, pp. 1115-1116, 2016. 7 (in Japa nese)

笹谷 満, 脇田 祥尚:クブック・テンガ（インドネシア・ロンボク島）にお ける住居平面構成, 日本建築学会大会学術講演梗概集, 建築計画, pp. 11151116, 2016. 7

6) Sasatani, M., Wakita, Y., Matsumoto, Y.: Changes in the composi tion of the residence plan in Lombok island, Indonesia, Summaries of Technical Papers of Annual Meeting, Architectural Institute of Japan, Architectural Planning and Design, pp. 1065-1066, 2017. 7 (in Japanese)

笹谷 満, 脇田 祥尚, 松本 友惟:インドネシア・ロンボク島における住居平 面 構成の変遷, 日本建築学会大会学術講演梗概集, 建築計画, pp. 10651066, 2017.7

7) Sasatani, M., Wakita, Y., Matsumoto, Y. : Research on living space in the initial period towards recovery after the Lombok earthquake in 2018, AIJ Journal of Technology and Design, Vol. 26, No.62, pp. 203-208, 2020.2 (in Japanese)

笹谷 満, 脇田 祥尚, 松本 友惟: ロンボク島地震（2018年）における生活再 建初動期の生活空間, 日本建築学会技術報告集, 26巻, 62号, pp. 203208, 2020. 2

8) Dampak Gempabumi Lombok 7 SR: https://bnpb.go.id/berita/dampakgempabumi-1ombok-7-sr, accessed 2021-1-30

9) Krishna Suryanto Pribadi, Rani Pradoto, Eliya Amilati Hanafi, I Made Adhi Bayu Rasmawan: Lombok earthquake, one year later: hous ing sector recovery, E3S Web of Conferences, 156(5), pp. 1-10, 2020 


\author{
Shusuke ARITOSHI ${ }^{* 1}$, Gregorius Agung SETYONUGROHO ${ }^{* 2}$, Norio MAKI*3, \\ Yoshihisa WAKITA *4, Yasushi TAKEUCHI ${ }^{* 5}$, Hon Shyan CHONG ${ }^{* 6}$ and Mitsuru SASATANI ${ }^{* 7}$ \\ *1 Former Grad. Stud., Graduate School of Engineering, Kyoto Univ., M.Eng. \\ *2 Lect., Faculty of Engineering, Atma Jaya Univ. Yogyakarta, M.Eng. \\ * 3 Prof., Disaster Prevention Research Institute, Kyoto Univ., Dr.Eng. \\ ${ }^{*} 4$ Prof., Faculty of Architecture, Kindai Univ., Dr.Eng. \\ ${ }^{*} 5$ Prof., Faculty of Architecture, Tohoku Institute of Technology, Dr.Eng. \\ ${ }^{*}{ }^{6}$ Prof., Faculty of Environmental Studies, Tottori Univ. of Environmental Studies, Dr.Eng. \\ ${ }^{*}$ Sekisui House, Ltd., M.Eng.
}

There are many unique living environments in Southeast Asia. Those environments often suffer from natural disasters. Support for rebuilding lives in rural villages is provided by a government, international organizations and NGOs. However, it is told that those support destroy the traditional way of living in impacted areas. This study spotlight to Bayan Timur village, which is famous for keeping their traditional cultural environment, and suffered from earthquake disaster in 2018, the 2018 Lombok earthquake.

We continue the field survey at this village from 1992, and also conducted the survey on damage soon after the event. This research targets to one year after, the phase of temporary recovery of housing. The goal of this study is to clarify the influence of damage, and temporary housing to the traditional living styles in Bayan Timur after the event. Field survey was conducted in August of 2019 .

After the disaster, many people lived outdoors, regardless of the damage to the main building due to the fear of the walls collapsing by the earthquake, they moved to places such as Berugak and terraces where the risk of damage is low. Receiving the provision of temporary shelter from NPO, many households moved bedroom and kitchen that had been in Berugak and terraces to the temporary shelters. The way of living mainly outdoors has changed to the way of living in temporary shelter. Before the provision of temporary shelter, Berugak was mainly used as a bedroom. Bedding was placed in Berugak, and furniture such as shelves were placed around Berugak, so it was far from the original space of Berugak. One year after the disaster, the living space was moved to a temporary shelter, and Berugak returned to its original space. Temporary shelter is thought to play a role in returning Berugak to its original space.

From the analysis of relation among temporary shelter, Berugak, and main building, the pre-disaster relation among Berugak and main building has recovered even though temporary shelter was injected and used as a bed room. It means that the traditional way of space use were resilient to impact from disaster such as building damage and temporary shelter construction. 